\title{
Dangseong fortress: archaeological evidence of the gateway to ancient gyoungju of the shilla dynasty on eastern silk-road
}

Keywords: Korean peninsula, silk road, shilla dynasty, gyoungju Introduction

In spite of series of discussions of Silk Road to Gyoungju, ancient capital of the Shilla dynasty, during the last several decades, few have been on main gateway of Korean peninsula for traffics of cultural exchanges during the ancient Korean history. ${ }^{1-5}$ If not Sea Silk Road through southern coast of East Asian part of the Eurasian continent, it is still a prime mission of the Silk road studies to find ancient cities in western coast of the Korean peninsula connecting China and Korea considering the location of Shilla in the southeastern part of the Korean peninsula which is isolated from any ancient ports in the western coastlines of the peninsula. This is a critical issue for understanding cultural exchange between Chinese mainland and Korean peninsula in ancient times through eastern Silk Road from Xian in China to Gyoungju in Korea.

As many cultural elements commonly appear in western Asia, especially Iran and in ancient Gyoungju; glass wares, stone sculpture, vessel forms, story of Persian prince and Shilla princesses, symbolic expressions etc, it has been a critical issue to find ancient route for human movements in discussion of the eastern Silk road. All objects from the other side of Eurasian continent, Iran, might not have been diffused directly, but more often through China, Tang dynasty during the ancient Shilla period. There are rich historical documents of cultural exchange between ancient Shilla and Tang as we can see in a famous mural of ancient tomb of Tang prince depicting delegate from Shilla. Numerous monks and scholars from Shilla studied in Tang, even prince of Shilla dynasty, Kim Inmun, for example. Regarding movements route of people and culture between China and Korea in ancient times, the most well-known story among Korean people is the one about famous Shilla monks, Eusang and Wonhyo. They left Gyoungju for Xian, China in order to study of Buddhism and arrived at Dangju, the Danghangseong in other name in historical text, ancient fortress in the Gyounggy province to across the Yellow Sea. Eusang continued his trip to Xian in $661 \mathrm{AD}$ and studied Buddhism at the Jisnagsa near the Xian, while Wonhyo went back to Gyoungju after enlightenment at the moment of drinking water in human skull in darkness. He found himself behave differently from his way of thinking a thing and realized that his preoccupied thinking made himself thinking same object differently. This philosophy of tranquility of mind leaded him found a new sector of Buddhism after his returning to Gyoungju. This story made the Danghangseong very famous in history of Korea and clearly indicates that Danghangseong fortress was quite likely the main gateway for Tang, ancient China at the time. However, it has not been know which mountain fortress is true one among many fortresses in the mid-western coastal region of Yellow Sea of the Korean peninsula. It is more and more likely that the current Dangseong is the Danghangseong upon observation of archaeological evidence collected from recent excavation of the site along with histo-geographical researches (Figure 1).
Volume 3 Issue I - 2018

\author{
Bae Kidong,' Kim Kiryong ${ }^{2}$ \\ 'Professor and Director of General National Museum of Korea, \\ South Korea \\ ${ }^{2}$ Director of Archaeological Research, Institute of East Asian \\ Archaeology, South Korea
}

Correspondence: Bae Kidong, Professor and Director of General National Museum of Korea, South Korea, Email bkd5374@gmail.com

Received: November 01, 2017 | Published: January 19, 2018

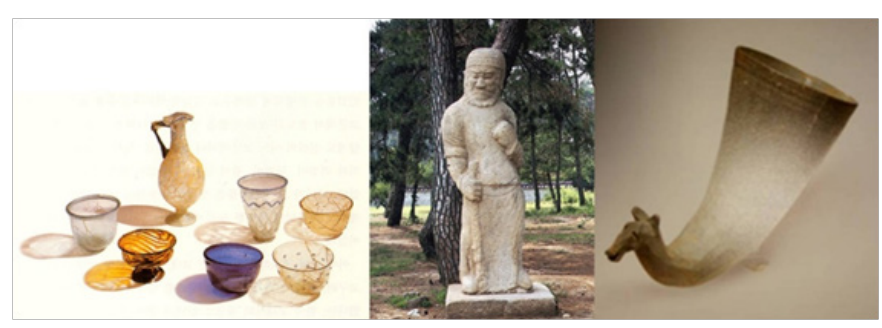

Figure I Archaeological objects of western influence from ancient Shilla sites in Gyoungju.

\section{Significance of the danghangseong in unification process}

During the Three Kingdoms period, Shilla occupied southeastern part of the Korean peninsula while Paekje did southwestern part. Goguryo in the northern part of the peninsula made their southern boundary around the Han River basin with Paekje in 5th century. Shilla King Jinheung took over the Lower Han River basin in order to open a direct and rapid contact with Tang in $550 \mathrm{AD}$ for its national security in conflicts between other kingdoms. Ever since the first occupation, Shilla never lost the Han River basin until the time of unification of the three kingdoms. It is evident that the Danghangseong fortress was the strategic center to keep the occupied region of central western coast which is part of the Han river basin and was considered stronghold for protecting trade route connecting the Tang dynasty for political and cultural exchange. In this sense, Danghangseong is a gateway of Silk Road for ancient Korea, particularly connecting to Gyoungju as we know of the Eussnag and Wonhyo story.

There are many different views of which one is the Danghangseong up to now among many fortresses situated along the mid-western coastal area. However, Dangseong has been thought to be very highly likely the Danghangseong because the name the fortress sounds very similar to the Dangseong although Chinese characters of the names are different. The name 'Dang' means 'Tang, ancient China'. Dangeunpo, name of a small town front of the Dangseong which means 'thank to the Tang', is believed the port for ships crossing the Yellow Sea. 
Above all, archaeological evidence from series of excavations in the last decade clearly supports that Dangseong is Danghangseong, which will be discussed in this article.

\section{Histo-geography of the dangseong}

The Dangseong is situated on the top of the mountain of near the coastline of the Yellow Sea in the Gyounggy Bay in mid-western part of the Korean peninsula. At the highest peak of the fortress, the pavilion of the Manghaeru is an observatory of views of all sides, looking down coastlines toward west and small hills to the east. It provides excellent point to make observation all movement under the hill around it. Above all, the Dangsung is the biggest fortress in central western coast of the Korena peninsula ${ }^{6,7}$ (Table 1). This fortress should have been definitely strategic platform for the Shilla dynasty to trade with Tang because the Shilla constructed extremely solid mountain fortresses such as the Samyonsanseong in Cheongju and Gyejoksanseong near Taejeon on the route connecting to the capital Gyoungju in the southeastern part of the peninsula for protection of traffic from and to the Dangseong. ${ }^{8}$ The Dangseong is currently situated a little bit away from modern coastline; however a sea channel connected to the current Dangeunpo in front of the Dangseong before the artificial reservoir, the Siwha lake was constructed two decades ago. In addition to the Dangeunpo, series of small pots were lined along the channel named 'Masan' in ancient times, even in early 20th century. Numerous archaeological sites including fortresses, ancient Buddhistic temple sites, ancient stone lined tombs etc. in adjacent area belong to the Three Kingdoms period, mostly to the Shilla dynasty. Dense distribution of diverse archaeological sites indicates very active human presence around the Dangseong in ancient times as a city. Chinese coins and bronze seal from stone lined tombs of the Goryo dynasty in nearby island, Daebu, ${ }^{9}$ is believed clearly represent people associated with active international trade (Figure 2).

Table I Length of fortress of ancient Shilla in the Han River basin

\begin{tabular}{ll} 
Fortress name & Perimeter(m) \\
\hline Dangsung & $\mathrm{I}, 450$ \\
Hoam & $\mathrm{I}, 400$ \\
Dok Mountain & $\mathrm{I}, 400$ \\
Gyeyang & $\mathrm{I}, 180$ \\
Morak & 878 \\
Jami & 582 \\
Suan & 578 \\
Sungtae & 372 \\
\hline
\end{tabular}

Five Archaeological campaigns of excavations of Dangsung Fortress have been carried out since the First Excavation in 1998. ${ }^{10-12}$ Valuable evidence for understanding function and structure of the fortress has been accumulated from these archaeological researches. Wall of the Dangsung fortress was constructed by piling rectangular stones and accumulating layers of earth up to several meters high. The first wall was small and surrounded a peak but it was expanded during the unified Shilla to occupy a valley on the other slope in the eastern part of the peak (Figure 2). It is believed that both, the first stage and second stage, of the stage of the fortress belong to the Shilla dynasty on basis of potteries and construction technique of wall in spite of claims the Paekje dynasty in its early stage of construction (Figures 3) (Figure 4).

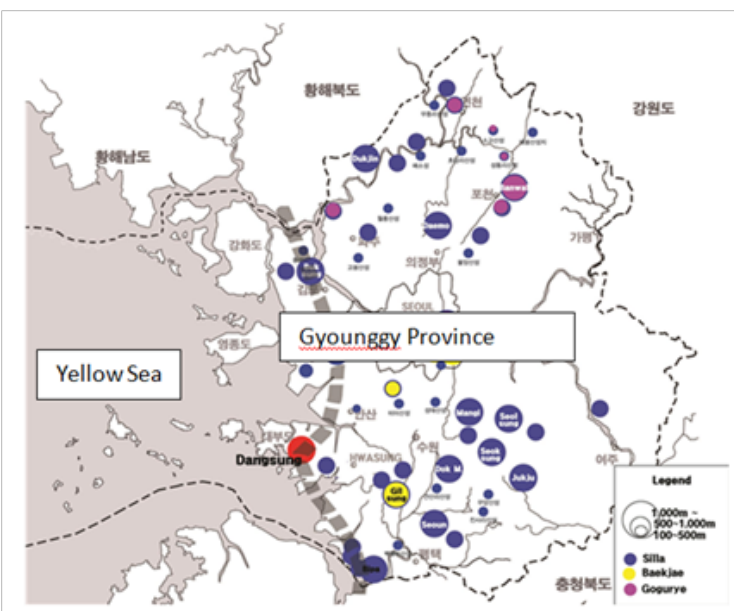

Figure 2 History of archaeological research and structure of the Dangseong.

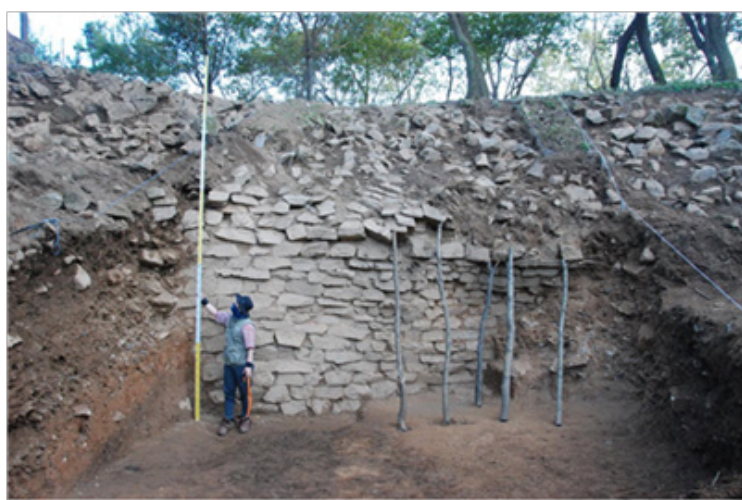

Figure 3 Stone Wall exposed in early fortress.

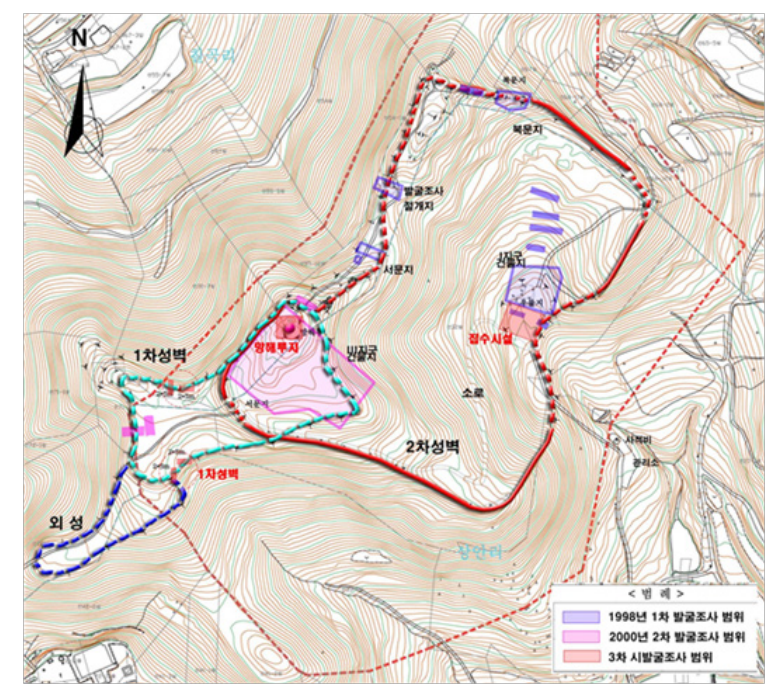

Figure 4 Map of Fortress $I^{\text {st }}$ and $2^{\text {nd }}$ stage.

Many buildings and a water reservoir were enclosed by wall constructed with rectangular stones and piled soil. Four gates connected inside to outside of the fortress. The hanging gate in western part of the fortress was probably used for emergency because it was built on very steep hill side toward sea. Major gate should have been the eastern gate opening toward east and leading a road along the small valley. It was constructed with huge stones by piling up on two drainage channels underneath for surface water 
from the valley inside of the fortress. On the highest peak in the fortress, a pavillion, named Manghaeru (meaning sea observatory), was built probably at the earliest stage of the fortress by the Shilla. The platform was constructed in a pattern applied by the Goguryoscale used by the Shilla. It provides clear view of all activities along the coastline and is being used a wonderful observatory of western coast for tourists. Foundation of the pavilion had been rebuilt several times up to the late Choseon dynasty. Files of roof tiles of different ages were retrieved from this site. Several structures were exposed near the pavilion on the eastern slope including octagonal structure, stone-lined heating floor, etc. Especially the octagonal structure is greatly importance in understanding the significance of the fortress. Similar structure was found in the Iseong mountain fortress near the Hanam city, east of Seoul. Octagonal building is unusual and assumed a ceremonial building for worshiping ancestor of dynasty. It indicates that the Dangseong was considered and used as an important regional center of local administration. The Isung fortress was quite likely the regional center of the Hansanju province of ancient Shilla, while Dangsung may have been a regional center in the western coast of the Han river basin because of this particular unusual building. Similar structure was also found in an ancient fortress in Kyushiu, Japan, and reconstructed to a three story building at the site. In addition to this special architect, several big foundations of buildings in the same area indicate great number of people stayed in the fortress. Stone lined structure, ondol, of heating floor indicates possibly permanent use of this fortress throughout year.

The rectangular water reservoir near a spring at the bottom of the valley in western part of the fortress also indicates a great numbered people stationed in the fortress. Around the reservoir, great quantity of iron ore and waste of smelting with slags were found with poor remains of furnace and atelier-like structures for possibly iron tool making. A rectangular water basin was made by piling up stones near the reservoir. Soil layers at the bottom of the basin are assumed associated with various industrial activities. This indicates diverse industrial works might have been done in the fortress not only military actions (Figure 5).

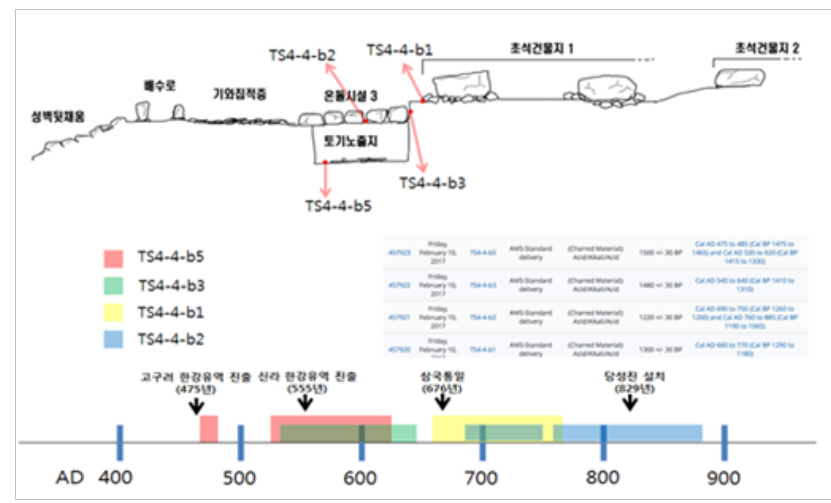

Figure 5 Chronological Distribution of archaeological features in the early fortress (I ${ }^{\text {st }}$ stage).

The building structures found in the early fortress looking down to the Dangeunpo in front of had been used since the earliest stage of the fortress possibly before the construction of the stone walls at the site according to the AMS date from the lowest layer where brown coloered pottery, possibly Paekje style, was exposed. This building site had been used for many renovations consistently from the earliest stage throughout to the Choseon dynasty. This building might have been used as administration center for government officers because of very high quality of vessels and other objects collected from these architect remains including two beautiful white porcelain bowls from Hebei in China. Dense distribution of architect structures in the area of the first stage may represent consistence use of the area for major activities of administration of the region (Figure 6).

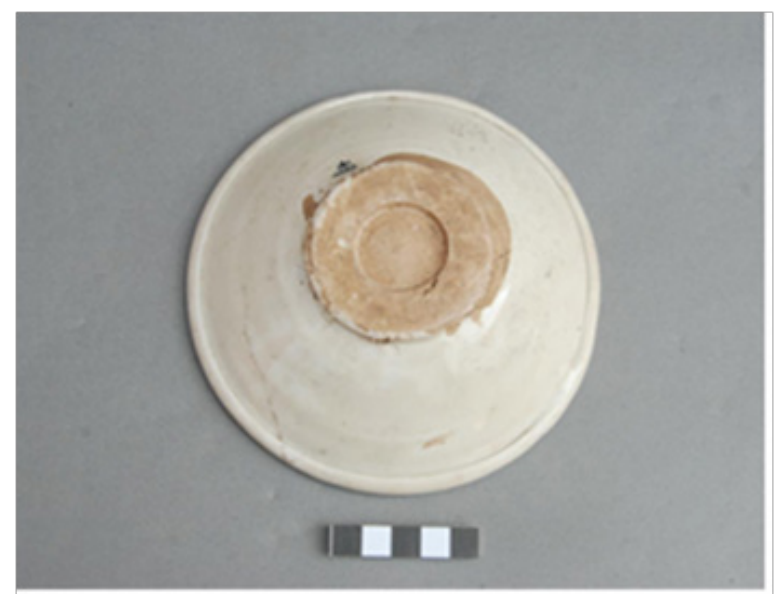

Figure 6 White porcelain tea bowl from Hebei, China.

\section{Strategic significance of the dangseong for shilla dynasty}

The most number of roof tiles with Chinese inscriptions were found at many different localities in the fortress among major mountain fortress in Korea up to now. Several Chinese inscriptions are considered great importance for understanding Shilla dynasty's view of this fortress in a perspective national strategic point. The sealed inscription of 'Bonpi' on one roof tile indicates administration officers were dispatched from the capital of the Shilla, ancient Gyoungju, to conduct the construction of the fortress. The Shilla dynasty often sent high official from the capital to construct important strategic fortress in the process of expansion of territory for solid construction. Inscription of 'Hansan' on one roof tile is the first one although 'Hansan' is known as name of the province of the Shilla Kingdom in the Lower Han river basin. This inscription indicates clearly that the Dangseong fortress is the key administration center in this region along with the main one of the Iseong fortress. There found many inscriptions stand for high official's house from series of excavations in last several years. The most critical find of roof tile with inscription was one with Chinese character, 'Dang' which is exactly the same character as 'Dang', current name of the Dangseong. On basis of find of the roof tile with letter of 'Dang (meaning group)', the Dang of the Danghangseong, could be considered a misspelled in historical document because the character 'Hang' in the middle of the name stand for ancient name of this region during the period of Goguryo occupation. This hypothesis may provide a good ground for thinking the Dangseong as the Danghangseong in the historical document, the Samguksagi (Figures 7) (Figure 8).

Horse terracotta figurine pieces collected from Manghaeru site may represent certain kind of ceremony for safe journey as we can see the Jukmagdong ancient ceremonial site in Buan, further south of the western coast, for safe voyage on the Yellow Sea. It is very likely that ceremony for safe sea journey was taken place at the Dangseong fortress for journey on the Yellwo Sea as well as on terrestrial roads to Gyoungju as similar finds in major mountain fortress of same period 
of Korean history. These remains also indicate that the Dangseong was a very important center for international trade and traffics of political purpose. This evidence may strengthen the representation of composite function of fortress not only for defense against enemy attacks but also for administrative and trading center (Figures 9) (Figure 10).

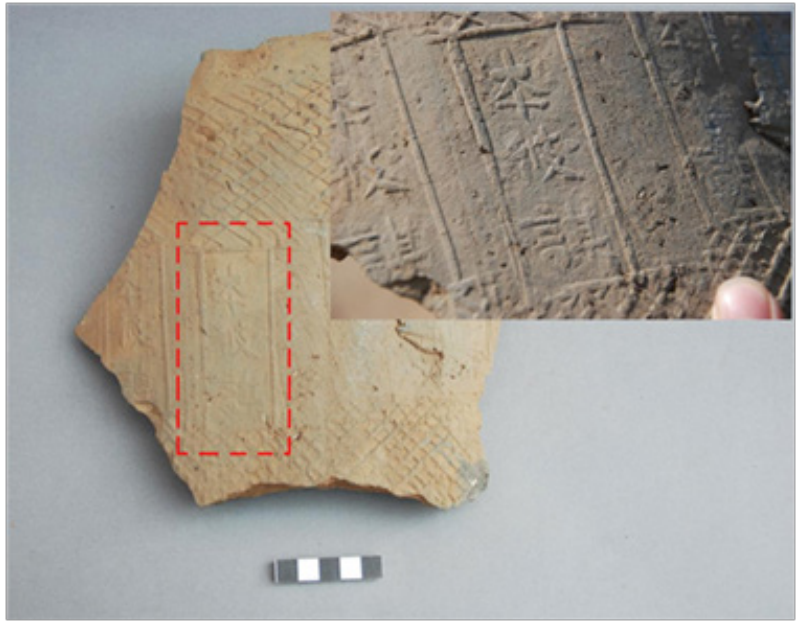

Figure 7 Bonpi, roof tile.

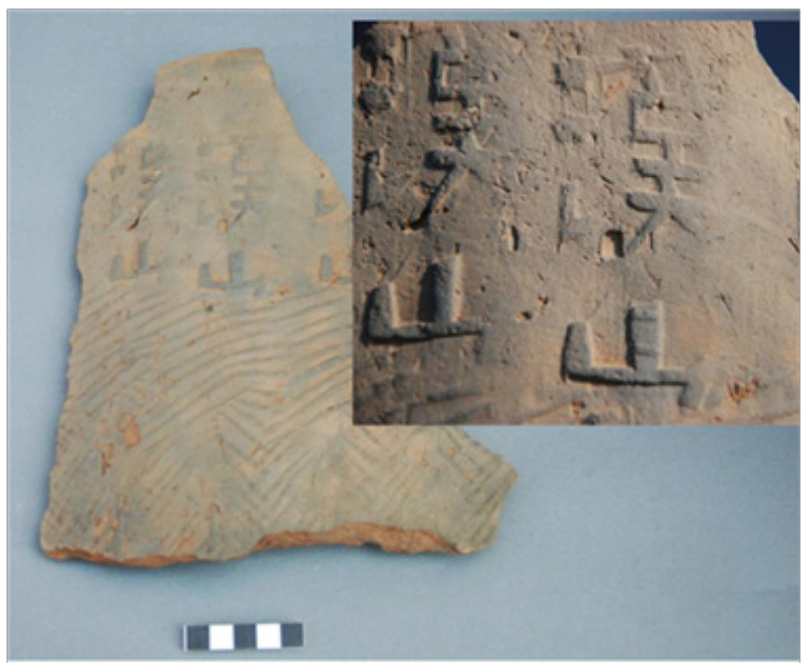

Figure 8 'Hansan', roof tile.

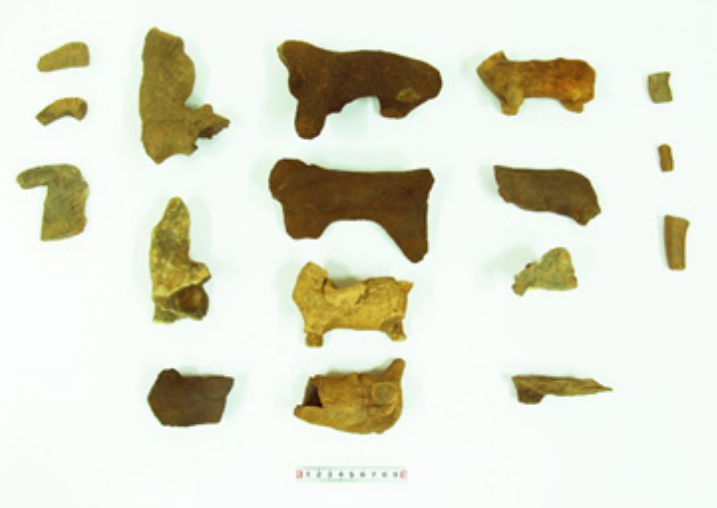

Figure 9 Horse terracotta figurine pieces."

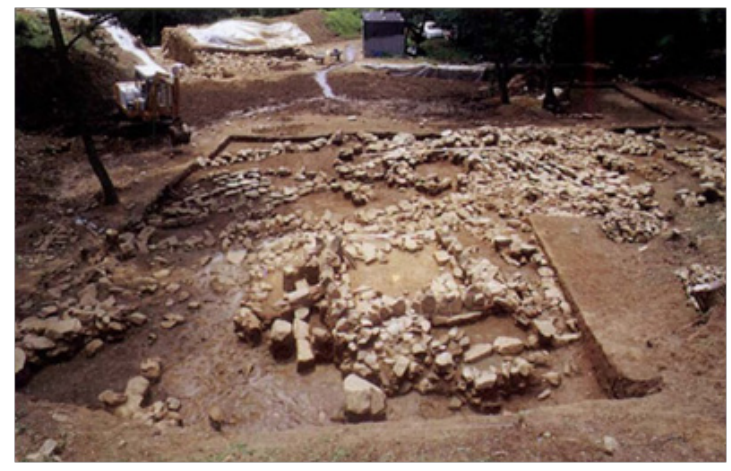

Figure 10 Dwelling sites with Ondol, floor heating system for permanent residence. 9

\section{Dangsung: the busiest gateway to gyoungju, ancient shilla on east asian silk road}

First of all, Dangseong is highly probable the Danghangseong appeared very critical strategic military platform in important historical documents on the basis of archaeological and histo-geographical evidence. Current archaeological evidence and geographical location indicate that Dangseong was the most frequently used gateway of Silk Road to and from Gyoungju, ancient Shilla, until the time of unification of the Three Kingdoms in the Korean peninsula and Manchuria. Archaeological evidence indicates that the fortress had been used since the time of Paekje occupation, however was expanded greatly by building up stone walls by the Shilla dynasty for defending trading ports for communication with Tang dynasty in China. The Dangseong was Shilla's strategic gateway for connecting Gyoungju and Xian in ancient history for political and cultural exchanges. In this regard, the Dangseong fortress was an important urban center for eastern Silk road from Xian (Figure 11).

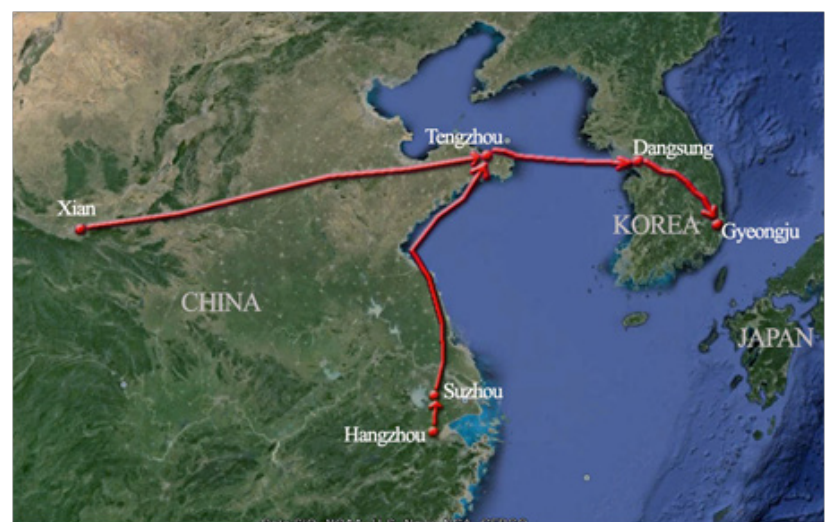

Figure II Eastern Silk Road from Xian, China to Gyoungju via Dangseong (=Dangsung).

\section{Conclusion}

It is especially notable that Shilla people's attempts to open and keep a new Silk Road at that time brought them with prosperity and success in unification of kingdoms in the peninsula and Manchuria. Archaeological evidence from this Dangseong fortress will be very significant for understanding how ancient Korean people received cultural flows through the eastern Silk road from Xian and diffused into the inside of the peninsula, and how much important in ancient times to keep intercultural relationship for development of each 
own society. This may give some deep insight for our thinking of sustainability nurished by multicultural communications in modern society.

\section{Acknowledgements}

None.

\section{Conflict of interest}

Author declares that there is no conflict of interest.

\section{References}

1. Bae KD. Culture of Dansung and Yellow Sea. Hakyeonmunhwasa, Korea; 2012.

2. Cha KH. The change of the Yellow Sea route in the 11th century, which is shown through the sea-interchanges between the Koryeo and Southeastern seaside of China. Journal of Civilization Exchanges. $2011 ; 2$.

3. Kim IH. The examination of the change of the sea route between Korea and China in the fourth to fifth centuries -of turning on the history of the exchanges. Journal of Civilization Exchanges. 2011;2.
4. Youn MC. Maritime Exchange and Saeway in Korea. Koreana. 2006;20:2

5. Youn MC. Re-recognition and application of East Asia's ocean space. Journal of East Asian Ancient Studies. 2006;14.

6. Bae KD, Lee HY, Kim SY, et al. The Master Plan for Conservation and Development The Iseong Mountain Fortress. The Institute of Cultural Properties in Hanyang University, Korea; 2007.

7. Bae KD, Lee HY, Kim SY, et al. The Master Plan for Conservation and Development The Iseong Mountain Fortress. The Institute of Cultural Properties in Hanyang University, Korea; 2012.

8. Seo YI. Traffic Routes in Shilla, Hakyeonmunhwasa, Korea; 1999.

9. Bae KD, Ahn SW, Lee HJ. The report of the Excavation Koryo Yuk-gol Tombs. Hanyang University Museum, South Korea; 2002.

10. Kim BM, Kim AK. The Report of the First Excavation Dansung Fortress. Hanyang University Museum, South Korea; 1998.

11. Bae KD, Park HM. The Report of the Second Excavation Dangsung Fortress. Hanyang University Museum, Korea; 2001.

12. Bae KD, Kim KR, Lee SH. Summary Report of the Excavation for Dangsung Fortress in Hwasung. The Institute of Cultural Properties in Hanyang University, Korea; 2016. 